AKTUALITA, Vol. 3 No.1 2020 hal. 130-146

\title{
PENYELESAIAN SENGKETA DAGANG INTERNASIONAL MELALUI MEDIASI SEBAGAI ALTERNATIF PENYELESAIAN SENGKETA PADA PEMILIHAN HUKUM DAN FORUM KONTRAK DAGANG INTERNASIONAL
}

\author{
Risa Restiyanda \\ Alumni Program Studi Magister Ilmu Hukum \\ Pascasarjana Universitas Islam Bandung \\ Email : risaresti53@gmail.com
}

\begin{abstract}
Abstrak : Sengketa dagang internasional merupakan kasus yang sering terjadi pada pelaku bisnis dalam suatu kontrak atau perjanjian. biasanya memiliki sistem hukum yang berbeda. Penyelesaian sengketa dagang internasional dapat ditempuh melalui litigasi dan non litigasi atau Alternatif Penyelesaian Sengketa. Tujuan dari penelitian ini untuk mengetahui penyelesaian sengketa dagang internasional melalui mediasi dihubungkan dengan pilihan hukum dan forum pada kontrak dagang internasional dan untuk mengetahui penggunaan hukum nasional dalam penyelesaian sengketa perdagangan internasional melalui mediasi ketika terjadi kekosongan hukum dalam forum penyeleseiannya terhadap kontrak dagang internasional. Metode yang digunakan adalah yuridis kualitatif, bersifat deskriptif analisis. Pengumpulan data dilakukan berdasarkan studi kepustakaan. Hasil penelitian ini adalah bahwa pilihan hukum dan forum dalam kontrak bisnis seharusnya dicantumkan oleh para pihak agar tidak menimbulkan permasalahan dikemudian hari, mediasi memang merupakan suatu pilihan alternatif penyelesaian kasus bisnis atau kasus perdagangan internasional yang harus dipertimbangkan pada tahap awal. Hal ini dikarenakan mediasi merupakan suatu forum penyelesaian yang lebih cepat dan murah, serta dapat menyediakan akses kepada para pihak yang bersengketa untuk memperoleh keadilan atau penyelesaian yang memuaskan atas sengketa yang dihadapi secara musyawarah. Terdapat Lex Loci Solutions sebagai rujukan untuk para pihak dalam membantu menyelesaikan kekosongan terhadap pilihan hukum dan juga forum penyelesaiannya.
\end{abstract}

Kata Kunci: Sengketa, Perdagangan, Internasional, Mediasi

\begin{abstract}
International trade disputes are cases that frequently occur in business actors in a contract or agreement. It usually has a different legal system. International trade dispute resolution can be pursued through litigation and non-litigation or Alternative Dispute Resolution. This study was conducted to discover the resolution of international trade disputes through mediation associated with the choice of law and forum on international trade contracts and to find out the use of national law in the resolution of international trade disputes through mediation when legal vacuum occurs in its resolution forum toward international trade contracts. This study used a qualitative juridical method with descriptive analysis. Data collection was conducted based on library study. The result indicated that the parties should list the choice of law and forum in business contracts not to cause problems later. Mediation is an alternative for solving business activities or international trade cases that must be considered at an early stage. This is because mediation is a faster and cheaper resolution forum, and able to provide access to the disputing parties to obtain justice or a satisfactory resolution of the disputes being faced in deliberation. There is Lex Loci Solutions as a reference for the parties in helping resolve the law vacuum toward the choice of resolution law and forum.
\end{abstract}


Keywords: Disputes, Trade, International, Mediation.

\section{A. PEndahuluan}

Sengketa dapat bermula dari berbagai potensi sengketa, salah satunya yaitu pada sengketa perdagangan internasional (Huala Adolf, 2015) karena umumnya dalam perdagangan internasional melibatkan 2 (dua) negara, adanya perbedaan hukum dari negara tersebut yang saling berbeda satu dengan lainnya, maka benturanbenturan hukum antar negara yang terlibat tidak dapat dihindari. Perdagangan internasional adalah pertukaran midal, barang adan jasa melintasi batas-batas negara atau wilayah, industrualisasi, maju transportasi, globalisasi, perusahaan multinasional, dan outsourcing semua memiliki dampak yang besar pada sistem perdagangan internasional. Perdagangan internasional merupakan sumber

utama pendapatan ekonomi untuk setiap negara (Huala Adolf, 2016).

Dalam setiap hubungan hukum yang dilakukan secara sengaja, para pihak menghendaki terjadinya akibat hukum. Namun demikian sering kali akibat hukum yang dikehendaki tersebut tidak berwujud. Hal ini yang mengakibatkan tidak terlaksananya akibat hukum karena adanya keenganan para pihak untuk melaksanakan prestasi atau bahkan kemungkinan adanya perbedaan pendapat para pihak terhadap hak dan kewajiban yang sebelumnya telah dirumuskan sendiri oleh mereka dalam perjanjian (Faiz Mufidi, 2005).

Banyaknya para pelaku usaha luar negeri dengan pelaku usaha lokal (swasta) yang melakukan kerjasama di bidang perdagangan sehingga apabila terjadinya sengketa internasional, perlunya suatu model penyelesaian sengketa yang dapat mengakomodasi kepentingankepentingan para pelaku usaha. Sementara itu penyelesaian sengketa konvensional yaitu pengadilan (Litigasi) memiliki kekurangankekurangan yang membuat model 
penyelesaian ini tidak lagi sesuai dengan tuntutan perkembangan zaman karna terlalu lama dan formalitas, Sedangkan bagi orangorang yang bergerak di dunia usaha yang senantiasa berfikir praktis (Ibid).

Terdapat dua macam bentuk penyelesaian sengketa. Pertama, model litigasi, yaitu penyelesaian sengketa yang dilakukan oleh lembaga peradilan, Kedua, Nonlitigasi atau Alternatif Dispute Resulution (ADR), yaitu penyelesaian di luar lembaga peradilan (out of court dispute settlement). alternatif penyelesaian sengketa adalah lembaga penyelesaian sengketa atau pendapat melalui prosedur yang disepakati para pihak, yakni penyelesaian diluar pengadilan dengan cara konsultasi, negosiasi, mediasi, konsiliasi, atau penilaian ahli."(UU No. 13 thn 1999). Mediasi merupakan suatu proses penyelesaian sengketa antara para pihak yang berselisih dengan memanfaatkan bantuan pihak ketiga yang independen untuk bertindak sebagai mediator (penengah), akan DOI: https://doi.org/10.29313/aktualita.v0i0.5689 tetapi tidak diberi wewenang untuk mengambil keputusan yang mengikat (Priyatna Abdurrasyid, 2015) Oleh karna itu, penyelesaian sengketa dagang secara mediasi menjadi cara yang paling banyak diminati karna tidak perlu waktu yang panjang dan juga biaya yang mahal, hanya saja perlu adanya pihak ketiga sebagai penegah dalam penyelesaiannya sebagai mediator. Modal utama penyelesaian sengketa adalah keinginan dan iktikad baik para pihak dalam mengakhiri persengketaan mereka. Keinginan dan iktikad baik ini, kadang-kadang memerlukan bantuan pihak ketiga dalam perwujudannya.

Kegiatan perdagangan dan transaksi bisnis Internasional dilakukan oleh para pihak berdasarkan kesepakatan yang dituangkan dalam suatu kontrak (perjanjian) internasional. Kontrak internasional memiliki posisi penting sebagai rujukan yang paling utama bagi para pihak dalam pelaksanaan suatu hal yang di perjanjikan, sampai pada penentuan bagaimana cara penyelesaian yang akan di tempuh 
jika dikemudian hari pelaksanaan kontrak tidak dapat di realisasikan sebagaimana mestinya, karna menurut Pasal 1338 Kitab UndangUndang Hukum Perdata menyatakan semua perjanjian yang di buat secara sah berlaku sebagai undang-undang bagi mereka yang membuatnya (KUHPdt Pasal 1338).

Praktek penggunaan APS termasuk mediasi tidak diikuti dengan pengaturan jelas mengenai pelaksanaanya. Seringkali penggunaan lembaga APS menjadi sia-sia karena salah satu pihak tidak mau melaksanakannya secara sukarela, sehingga banyak pihak mempertanyakan perihal kepastian hukum penggunaan lembaga mediasi. Masalah atau akibat hukum yang mungkin timbul sebagai akibat dari penggunaan lembaga APS termasuk mediasi sebagai alternatif penyelesaian sengketa. Gambaran keadaan di atas, menarik dan mendorong perhatian penulis untuk mengadakan penelitian mengenai forum mediasi sebagai alternatif penyelesaian sengketa. Adapun identifikasi masalah nya yang pertama yaitu Bagaimana penyelesaian sengketa dagang internasional melalui mediasi dihubungkan dengan pilihan hukum dan forum para pihak dalam kontrak dagang internasional? dan Bagaimana penggunaan hukum nasional dalam penyelesaian sengketa perdagangan internasional melalui mediasi dalam hal terjadi kekosongan hukum dalam dalam kontrak dagang internasional berdasarkan teori lex loci solutions? Sedangkan tujuan penelitian ini yaitu Untuk mengetahui penyelesaian sengketa dagang internasional melalui mediasi dihubungkan dengan pilihan hukum dan forum para pihak dalam kontrak dagang internasional Untuk mengetahui penggunaan hukum nasional dalam penyelesaian sengketa perdagangan internasional melalui mediasi dalam hal terjadi kekosongan hukum dalam dalam kontrak dagang internasional berdasarkan teori lex loci solutions.

\section{B. PEMBAhaSAN}

1. Pelaksanaan penyelesaian sengketa dagang internasional 
melalui mediasi dihubungkan dengan pemilihan hukum dan forum para pihak dalam kontrak dagang internasional

Sengketa yang terjadi karena terjadinya kekosongan hukum dalam suatu kontrak yang didalamnya tidak ada klausul tentang bagaimana cara penyelesaiannya apabila terjadi sengketa. Misalnya, dalam kontrak dagang internasional yang dilakukan oleh pelaku bisnis yang berbeda kewarganegaraannya, tentunya pemilihan forum dalam penyelesainnya tentu akan menjadi konfik kedua belah pihak karna kedua belah pihak mempunyai sistem hukum yang berbeda. Pasal 6 ayat (1) UU No. 30 tahun 1999 menerangkan bahwa sengketa atau beda pendapat perdata dapat di selesaikan oleh para pihak melalui alternatif penyelesaian sengketa yang di dasarkan pada iktikad baik dengan mengesampingkan penyelesaian secara litigasi di Pengadilan Negeri. Ayat ini memberikan penegasan bahwa tujuan APS adalah penyelesaian melalui jalur non litigasi. Jalur ini bisa ditempuh jika

DOI: https://doi.org/10.29313/aktualita.v0i0.5689 para pihak yang bersengketa memiliki iktikad baik untuk melakukan perdamaian.

Ayat (2) menjelaskan bahwa Penyelesaian sengketa atau beda pendapat melalui alternatif penyelesaian sengketa sebagaimana dimaksud dalam ayat (1) diselesaikan dalam pertemuan langsung oleh para pihak dalam waktu paling lama 14 (empat belas) hari dan hasilnya dituangkan dalam suatu kesepakatan tertulis. Ayat ini menjelaskan bahwa perselisihan atau sengketa dapat diselesaikan oleh masing-masing pihak tanpa adanya keterlibatan pihak ketiga. Penyelesaian jenis ini disebut negosiasi. Dalam negosiasi para pihak sendirilah yang akan melakukan kompromi-kompromi atas masalah yang dihadapinya. (Bambang Sutyoso, 2017). Selanjutnya ayat (3) berbunyi Dalam hal sengketa atau beda pendapat sebagaimana dimaksud dalam ayat (2) tidak dapat diselesaikan, maka atas kesepakatan tertulis para pihak, sengketa atau beda pendapat diselesaikan melalui bantuan seorang 
atau lebih penasehat ahli maupun melalui seorang mediator. mediator berkedudukan sebagai pembantu, walaupun ada unsur intervensi terhadap pihak-pihak yang sedang berseteru. Dalam kondisi demikian, mediator harus bersifat netral sampai diperoleh keputusan yang hanya ditentukan oleh para pihak. Hanya saja dalam penyelesaian konflik tersebut mediator bersifat aktif membantu para pihak menemukan berbagai perbedaan persepsi atau pandangan. Mediator akan mempelajari bukti-bukti dari kedua belah pihak dan menawarkan solusi yang adil untuk diterima sebagai kesepakatan bersama. Mediator hanya menawarkan usulan yang positif dan tidak memihak, namun keputusan akhir tetap menjadi keputusan kedua belah pihak yang bersifat pribadi dan rahasia serta tidak dipublikasikan. Mediator harus bersikap netral, membina hubungan baik, berbicara dengan bahasa yang dipahami kedua belah pihak, mendengarkan secara aktif, menekankan pada keuntungan potensial, meminimalkan perbedaan, dan menitikberatkan persamaan. Dan apabila kesepakatan telah dicapai maka perdamaian dari mediasi ini dimohonkan ke Pengadilan untuk dikuatkan dalam Akta Perdamaian. (Iswi Hariyani, Cita Yustisia Serfiani, R. Serfianto,2016) Keterlibatan pihak ketiga tentulah orang yang disepakati oleh kedua belah pihak yang bersengketa. Ia harus orang yang adil, tidak memihak (netral) dan memiliki skill tentang objek sengketa, Namun jika mengalami kegagalan dalam mediasi, maka penyelesaian sengketa dapat dilakukan dengan cara arbitrase. Memperhatikan ayat (4) tersebut, maka arbitrase dipandang sebagai solusi setelah negosiasi dan mediasi mengalami kegagalan. Meskipun ayat ini menyebut pranata APS lain selain arbitrase, namun tidak ada pranata lain yang dipandang efektif dibanding arbitrase. Ketentuan ini diatur dalam ayat 5 sampai 9. Berdasarkan Pasal di atas maka arbitrase dilakukan dalam waktu paling lama 30 (tigapuluh) hari dan jika masih mengalami kegagalan maka dapat 
mengajukan penyelesaian sengketa melalui lembaga arbitrase ad-hoc. Pemilihan penyelesaian sengketa melalui arbitrase ad-hoc ini meruapakan pilihan terakhir. Dengan cara ini maka sengketa diharapkan bisa selesai melalui arbiter(Bambang Sutyoso, 2017) Dalam Pasal 15 tentang hukum yang berlaku dalam Peraturan dan Prosedur Arbitrase di Badan Arbitrease Nasional Indonesia Hukum Yang Berlaku yaitu hukum yang mengatur sengketa adalah hukum yang dipilih dalam perjanjian komersial bersangkutan yang menimbulkan sengketa antara para pihak. Dalam hal oleh para pihak dalam perjanjian tidak ditetapkan tentang hukum yang mengatur, para pihak bebas memilih hukum yang berlaku berdasarkan kesepakatan bersama. Dalam hal kesepakatan itu tidak ada, majelis arbitrase atau arbiter tunggal berhak menerapkan ketentuan-ketentuan hukum yang dianggap perlu, dengan mempertimbangkan keadaankeadaan yang menyangkut permasalahannya. Kesepakatan para pihak dalam suatu perjanjian untuk DOI: https://doi.org/10.29313/aktualita.v0i0.5689 memilih yurisdiksi dan pilihan hukum yang berlaku tetap dikembalikan pada penerapan dari asas kebebasan berkontrak (pacta sun servanda) sebagaimana dimaksud dalam Pasal 1338 KUHP Bahwa dalam implementasi dari asas kebebasan berkontrak yang sifatnya universal dalam suatu perjanjian juga tergantung pada posisi tawar menawar (bargaining power) di antara para pihak.( Budiman N.P.D Sinaga,2017)

Mediasi tidak selalu tepat untuk diterapkan terhadap semua sengketa atau tidak selalu diperlukan untuk menyelesaikan semua persoalan dalam sengketa tertentu. Mediasi akan berhasil atau berfungsi dengan baik bilamana sesuai dengan syarat-syarat. Syarat-syarat tersebut di antaranya, para pihak mempunyai kekuatan tawar menawar yang sebanding, para pihak menaruh perhatian terhadap hubungan di masa depan, terdapat persoalan yang memungkinkan terjadinya pertukaran (trade offs), terdapat urgensi atau batas waktu untuk menyelesaikan, tidak memiliki permusuhan yang 
berlangsung lama dan mendalam, apabila para pihak mempunyai pendukung atau pengikut, mereka tidak dapat dikendalikan, menetapkan preseden atau mempertahankan suatu hak tidak lebih penting dibandingkan menyelesaikan persoalan yang mendesak, dan yang terakhir, jika para pihak berada dalam proses litigasi, kepetingankepentingan lainnya tidak akan diperlakukan lebih baik dibandingkan mediasi.

Menurut BANI hasil akhir dari proses mediasi adalah kesepakatan perdamaian yang pelaksanaannya tergantung pada itikad baik dari para pihak, lain halnya dengan mediasi yang dilakukan dalam proses arbitrase yang dilakukan di BANI. Jika proses mediasi berhasil, maka para pihak menuangkan kesepakatan medasi mereka melalui akta perdamaian, akta perdamaian tersebut kemudian dituangkan dalam suatu putusan arbitrase yang final dan mengikat para pihak. Proses ini dinamakan dengan Hybrid-arbitration. Hal ini tentu saja bisa jadi gambaran untuk para pembaca tentang perbedaan mediasi saja dengan mediasiarbitrase. Pengaturan tentang Mediasi sendiri belum cukup diatur dalam perundang-undangan di Indonesia sehingga sangat dirasakan kekurangan dan kelemahannya terhadap penyelesaian sengketa. Sedangkan pengaturan tentang arbitrase maupun Hybird-arbitrase di Indonesia perlu lagi disempurnakan dengan mengacu pada UNCITRAL Model Law. Sedangkan dalam penyelesaian sengketa melalui mediasi didasarkan pada interest based atau bertumpu kepada kepentingan para pihak, tidak menjadi larangan apabila para pihak mempunyai sistem hukum yang berbeda tetapi lebih kepada kepentingan para pihak untuk menyelesaian sengeketanya. Sedangkan terkait biaya berperkara di BANI meliputi biaya pendaftaran, biaya admnistrasi yang memiliki nilai tuntutan yang berbeda, biaya pemanggilan, biaya transportasi arbiter atau mediator, biaya persidangan yang dilakukan ditempat lain selain di BANI, biaya 
pendaftaran putusan di Pengadilan Negeri yang bersangkutan, dan yang terakhir biaya pajak.

$$
\text { Pada umumnya para }
$$
pengusaha pemula kurang menyadari pentingnya membuat kontrak dagang yang baik dan benar sehingga sering kali mereka mengalami kekalahan pada saat terjadi sengketa. Bagi orang yang paham hukum, kontrak bisnis dapat dipakai sebagai alat ampuh untuk mengalahkan lawan di persidangan. Kontrak atau perjanjian memiliki kekuatan hukum layaknya Undang-undang bagi para pembuatnya. Tanpa adanya kontrak, penyelesaian sengketa akan semakin sulit dilakukan (Iswi Hariyani, Cita Yustisia Serfiani, R. Serfianto,2016)

2. Penggunaan hukum nasional dalam penyelesaian sengketa perdagangan internasional melalui mediasi dalam hal terjadi kekosongan hukum dalam forum penyelesaiannya terhadap kontrak dagang internasional dihubungkan dengan teori lex loci solutions

Kontrak yang dibuat para pihak yang berbeda kewarganegaraanya tetap terikat pada suatu hukum nasional tertentu (dari suatu negara) atau Lex Contractus. Pada prinsipnya tidak ada suatu kontrak yang tidak tunduk pada suatu hukum nasional tertentu. Jadi hukum nasional itu sebenarnya hukum dari masing-masing pihak yang akan dipakai untuk kontrak tersebut. Dari adanya keterkaitan erat antara hukum nasional dengan kontrak internasional mensyaratkan bahwa pemahaman suatu hukum nasional (dalam hal ini hukum perjanjian Indonesia) adalah suatu hal yang penting. Pemahaman terhadap hukum nasional juga relavan untuk mengetahui keabsahaan suatu kontrak, dan apakah ada syarat tertentu harus dipenuhi untuk suatu bentuk kontrak tertentu.

Huala Adolf menyatakan bahwa jika dalam pilihan hukum (choice of law) memilih hukum Indonesia maka tidak serta pengadilan yang berwenang menyelesaikan perkara tersebut adalah pengadilan Indonesia (choice of forum). Begitu juga jika para 
pihak memilih pengadilan Indonesia dalam pilihan forumnya maka tidak serta merta pilihan hukumnya adalah hukum Indonesia. Namun demikian para pihak diberikan kebebasan untuk memilih hukum dan forum pada suatu negara tertentu,memilih hukum Indonesia dan memilih forum Pengadilan Indonesia (Sudargo Gautama, 1976).

Menurut Sudargo Gautama pilihan hukum adalah kebebasan yang diberikan kepada para pihak dalam bidang perjanjian untuk memilih sendiri hukum yang hendak dipergunakan. Para pihak mendapat kebebasan untuk memilih hukum yang diperlakukan untuk perjanjian mereka. Diberikannya pilihan hukum dalam kontrak internasional berawal dari diakuinya konsep kebebasan berkontrak dalam hukum perdata. Hukum yang dapat dipilih oleh para pihak dalam sebuah kontrak internasional menurut Huala Adolf adalah hukum nasional suatu negara, khususnya hukum nasional dari salah satu pihak, hukum kebiasaan, perjanjian internasional dan hukum

DOI: https://doi.org/10.29313/aktualita.v0i0.5689 internasional( Sudargo Gautama, 1980)

Para ahli memandang bahwa pilihan hukum merupakan hal penting dalam sebuah kontrak internasional, Schmitthoff memandang bahwa kontrak internasional yang tidak terdapat klausul pilihan hukumnya atau terjadi kekosongan hukum merupakan kontrak yang cacat. Di samping itu UNCITRAL menganjurkan agar pelaku bisnis internasional dalam membuat kontrak internasional sebaiknya mencantumkan klausul pilihan hukum sebagai langkah antisipatif untuk mencegah ketidakpastian hukum pada waktu penyelesaian sengketanya.

Penggunaan teori lex loci solutions setidaknya akan memberikan jalan keluar dalam permasalahan ini, karna menurut teori ini yaitu "Hukum yang berlaku dalam kontrak adalah hukum dilaksanakannya kontrak". Tentu hal ini akan menjadi titik temu dalam penggunaan hukum nasionalnya, karna kontrak itu dilaksanakan 
sepenuhnya menjadi pilihan hukum untuk penyelesaian sengketa. Tapi tetap harus dapat dilihat dari masingmasing sengketanya. Karna biasanya setiap sengketa seperti ini mempunyai beberapa hukum yang berlaku juga titik taut primer dan sekunder yang berbeda, lalu di laksanakannya kontrak tersebut (lex loci solutions) seperti namanya ini merupakan solusi yang menurut penulis terbaik karna tentu saja setiap kontrak mempunyai tujuan nya dan tujuan tersebut akan dilaksanakan hal ini tentu lebih memudahkan untuk memilihnya karna apabila para pihak memiliki sistem hukum yang berbeda dengan di gunakannya teori ini akan menjadi jalan keluarnya karna akan menitik beratkan hal tersebut kepada dilaksanakannya kontrak tersebut walaupun nanti akan berbeda sistem hukum dari para pihak. Hukum tempat perbuatan melawan hukum dilakukan (lex loci delicti commisi), hukum dari pengadilan atau hakim (lex fori) dalam hal ini karna forumnya dilakukan secara mediasi yaitu mediator sebagai penengahnya

DOI: https://doi.org/10.29313/aktualita.v0i0.5689 berarti tidak akan melihat dari sistem hukum hakim, dan hukum dari salah satu pihak yang melakukan prestasi (the most characteritic connection).

\section{PENUTUP}

\section{Kesimpulan}

(1) Kontrak atau perjanjian memiliki kekuatan hukum layaknya Undang-undang bagi para pembuatnya. para pihak bebas memilih hukum yang berlaku berdasarkan kesepakatan bersama, Kesepakatan para pihak dalam suatu perjanjian untuk memilih yurisdiksi dan pilihan hukum yang berlaku tetap dikembalikan pada penerapan dari asas kebebasan berkontrak (pacta sun servanda) sebagaimana dimaksud dalam Pasal 1338 Kitab UndangUndang Hukum Perdata, Makna nya dalam pasal tersebut bahwa peraturan perundang-undangan Indonesia yang menyangkut status dan kewenangan seseorang, mengikuti orang tersebut kemanapun ia pergi. Prinsip ini dalam ilmu hukum 
perdata internasional dikenal sebagai prinsip nasionalitas (nationality principle). Dengan ketentuan ini, maka jika seseorang Indonesia yang sedang berada di luar negeri akan menandatangani suatu kontrak bisnis, maka penentuan status dan kewenangannya untuk melakukan tindakan hukum dilakukan menurut hukum nasionalnya (Indonesia).

(2) Kontrak yang dibuat para pihak yang berbeda kewarganegaraanya tetap terikat pada suatu hukum nasional tertentu (dari suatu negara) atau Lex Contractus. Pada prinsipnya tidak ada suatu kontrak yang tidak tunduk pada suatu hukum nasional tertentu. Hanya saja tergantung para pihak saja lagi untu menentukan hukum nasional mana yang akan digunakan. Dengan bantuan mediator tentunya akan menjadi bantuan untuk para pihak menentukannya dengan menggunakan teori lex loci solutions setidaknya akan memberikan jalan keluar dalam permasalahan ini, karna menurut teori ini yaitu "hukum yang berlaku dalam kontrak adalah hukum dilaksanakannya kontrak". Tentu hal ini akan menjadi titik temu dalam penggunaan hukum nasionalnya, karna kontrak tersebut dilaksanakan sepenuhnya menjadi pilihan hukum untuk penyelesaian pilihan hukum dari para pihak

\section{Saran}

(1) Perlu adanya sosialisi tentang mediasi sebagai altertnatif penyelesaian sengketa dalam kasus Perdaganagan Internasional, Agar pemerintah mengamendemen Undangundang yang ada atau membuat Undang-undang baru mengenai mediasi agar ada kepastian hukum dalam penanganan awal sampai pada penyelesaian akhir, Agar RUU mengenai Hukum Perdata Internasional dapat segerah disahkan menjadi UU. 
(2) Pada Kesimpulan Kedua maka saran dari penulis yaitu : Perlu adanya rekonseotualisasi mediasi dalam Undang-undang Nomor 30 tahun 1999 demi terwujudnya peradilan yang sederhana, cepat dan biaya ringan Perlu adanya peningkatan SDM yang kompeten dan bersertifikasi sebagai mediator, apalagi dalam kasus perdagangan internasional yang pasti membutuhkan kemampuan berbagai bahasa. Berhati-hatilah ketika membuat kontrak atau perjanjian bisnis,
(3) jangan lupa menyantumkan klausul-klausul tentang penyelesaian sengeketa, pilihan hukumnya, dan forum penyelesaiannya. Agar apabila dikemudian hari terjadi sengketa dapat dilakukan sesuai perjanjian yang dilakukan. Tidak ada salahnya bertanya dan berkonsultasi kepada siapapun yang ahli dalam bidang kontrak atau bisnis internasional sebelum kesepatan terjadi.

\section{DAFTAR PUSTAKA}

\section{A. Buku}

Bambang Sutiyoso, Hukum Arbitrase

Dan Alternatif Penyelesaian

Sengketa.Yogyakarta, Gama

Media, 2008.

Budiman N.P.D Sinaga, Hukum

Kontrak dan Penyelesaian

Sengketa dari Perspektif

Sekretaris, Jakarta, PT. Raja

Grafindo Persada, 2005.

Frans Hendra WInarta, Hukum

Penyelesaian Sengketa-

Arbitrase Nasional
Indonesia

$\&$

Internasional', Jakarta,Sinar

Grafika Offset,2011.

Hanitijo Soemitro, Metode

Penelitian Hukum dan

Jurimetri, Cetakan ketiga

Ghalia Indonesia, Jakarta, 1988

Huala Adolf, Hukum Penyelesaian Sengketa Internasional, Jakarta, Sinar Grafika, 2004. 


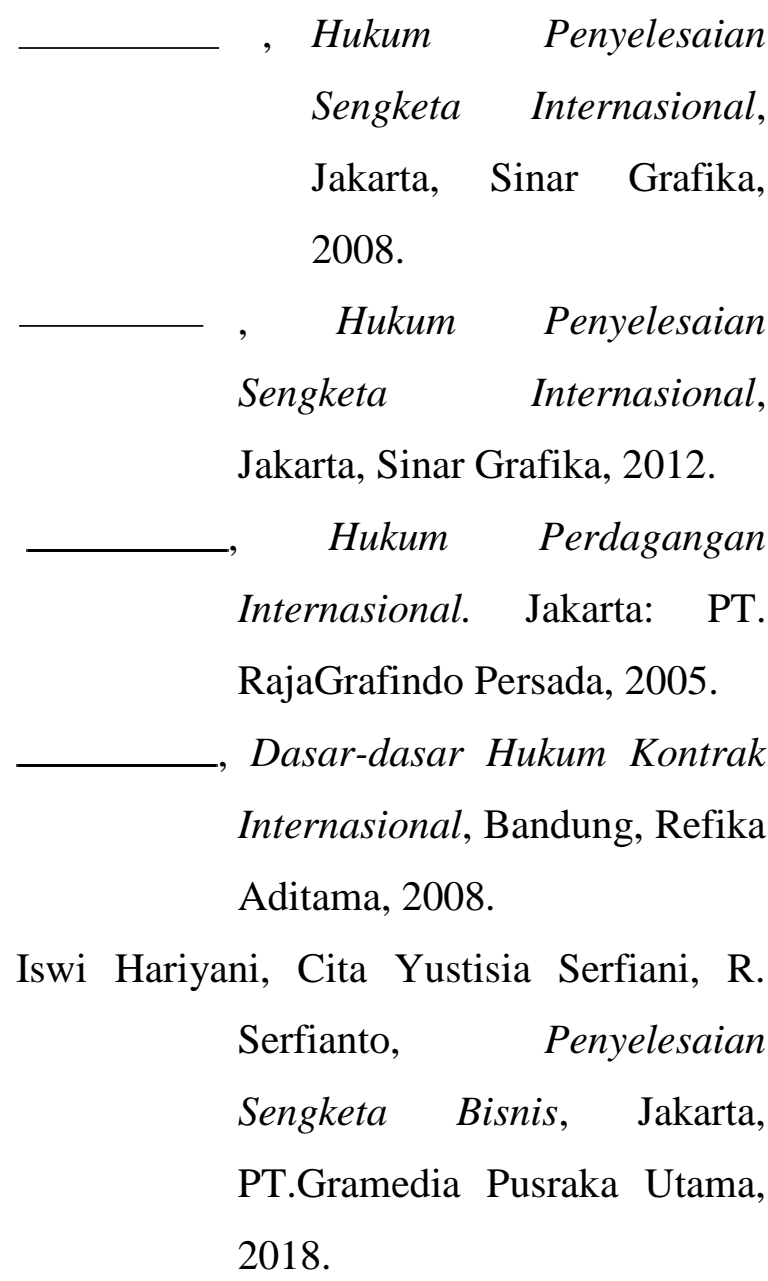

M. Yahya Harahap, Beberapa Tinjauan Mengenai Sistem Peradilan dan Penyelesaian Sengketa, PT. Citra Aditya Bakti, Bandung, 1997.

Munir Fuady, Arbitrase Nasional (Alternatif Penyelesaian Sengketa Bisnis),Bandung, PT.Citra Aditia Bakti, 2003.

$\longrightarrow$ Hukum Kontrak (dari
Sudut Pandang Hukum
Bisnis), Bandung: PT.
DOI: https://doi.org/10.29313/aktualita.v0i0.5689

Citra Aditya Bakti, 2001.

Peter Mahmud Marzuki , Penelitian Hukum, Jakarta, Kencana Prenada Media Grub, 2011.

Priyatna Abdurrasyid, Arbitrase dan Alternatif Penyelesaian Sengketa Suatu Pengantar, PT. Fikahati Aneska, Jakarta, 2002.

Priyatna Abdurrasyid, Arbitrase dan Alternatid Penyelesaian Sengketa (APS) Suatu Pengantar, Jakarta, Fikahati Aneska, 2011.

Sayud Margono, Alternatif Dispute Resolution dan Arbitrase: Proses Pelembagaan dan Aspek Hukum, Jakarta, Ghalia Indonesia, 2002. Salim H.S, Hukum Kontrak (Teori dan Teknik Penyusunan Kontrak), Jakarta, Sinar Grafika, 2003.

Sudargo Gautama, Hukum Dagang Internasional, Bandung, Alumni,1980. 
Risa Restiyanda, Penyelesaian Sengketa Dagang Internasional Melalui Mediasi Sebagai Alternatif....

Kontrak Dagang Internasional,

Bandung: Alumni, 1976.

, Hukum Perdata Internasional

Indonesia, Jilid II Bagian 4

Buku Ke-5, Alumni, Bandung, 1998.

Soerjono Soekanto \& Sri Mamudji,

Penelitian Hukum Normatif

(Suatu Tinjauan Singkat),

Rajawali Pers, Jakarta, 2001.

Soedjono Dirdjosisworo, Pengantar Hukum

Dagang Internasional,

Bandung, Refika Aditama, 2006.

Syahrizal Abbas, Mediasi Dalam Perspektif

Hukum Syariah, Hukum Adat dan Hukum Nasional, Jakarta,Kencana, 2011.

Takdir Rahmadi, Mediasi Penyelesaian

Sengketa Melalui Pendekatan

Mufakat, Jakarta,RajaGrafindo, 2010.

Usman Rahmadi, Pilihan Penyelesaian

Sengketa Di Luar Pengadilan, Bandung, Citra Adhitya Bakti, 2003.

\section{B. Peraturan Perundang-Undangan}

Undang-undang No.30 Tahun 1999 tentang

Arbitrase dan Alternatif

Penyelesaian Sengketa

Kitab Undang-undang Hukum Perdata.

DOI: https://doi.org/10.29313/aktualita.v0i0.5689
Perma No.1 tahun 2016 tentang

Prosedur Mediasi

\section{Sumber Lain}

Benny Asrianto, Oksep Adhayanto

"Penyelesaian Sengketa

Dagang Dalama Hukum

Internasional", Vol 1

No.2, Jurnal Selat 2004.

Cicut Sutiarso, Tesis: Arbitrase sebagai Bentuk

Penyelesaian Sengketa

dihubungkan dengan Asas

Peradilan menurut Hukum

Positif dan Hukum Islam,

Universitas

Islam

Bandung,2002.

Cut Memi, Penerapan Klausul

Pilihan Yuridiksi (Choice

of Juridiction) dan

Pilihan Hukum (Choice of

Law) Dalam Penyelesaian

Sengketa Bisinis

Internasional, Jurnal

Hukum, Vol 2,

No.2,Oktober 2017.

Damos Dumoli Agusman, "Status

Hukum Perjanjian

Internasional dalam

Hukum Nasional RI

(Tinjauan Dari Perspektif 
Risa Restiyanda, Penyelesaian Sengketa Dagang Internasional Melalui Mediasi Sebagai Alternatif....

Praktik Indonesia", Vol 5

No.3, Jurnal Hukum

Internasional, 3 April

2008.

Dianto Satio Prabowo, Tesis: Kewenangan

BPSK dalam Penyelesaian

Sengketa Perjanjian

Pembiayaan Menurut UU No.8

tahun $1999 \quad$ tentang

Perlindungan Konsumen Jo UU

No..30 tahun 1999 tentang

Arbitrase dan Alternatif

Penyelesaian

Sengketa,Universitas Islam

Bandung, 2018.

M. Faiz Mufidi, Alternatif Penyelesaian

Sengketa Menurut Undangundang no. 30 Tahun 1999

tentang Arbitrase dan Alternatif

Penyelesaian Sengketa, Jurnal

Hukum, Vol. VII No.3 November

2005 300-317, Bandung.

M. Faiz Mufidi, "Beberapa Catatan tentang

Pengakuan dan Pelaksanaan

Putusan Arbitrase Asing di

Indonesia", dalam Jurnal Ilmu

Hukum Litigasi, Vol 5, Nomor 1,

Februari 2004, Bandung.

Nurul Fitriyana, Skripsi :Implementasi

PERMA No.1 tahun 2008 tentang

DOI: https://doi.org/10.29313/aktualita.v0i0.5689 prosedurmediasi di pengadilan dalam perkara perceraia (Studi diPengadilan Agama Kota Semarang), 2011, Institut Agama Islam Negeri Walisongo, Semarang.

Revy S.M. Korah, Mediasi Merupakan Salah Satu Alternatif Penyelesaian Masalah Dalam

Sengketa Perdagangan Internasional, Jurnal Hukum, Volume 21 No.3, April-Juni 2013.

Subianta Mandala, Harmonisasi

Hukum Perdagangan

Internasional: Sejarah, Latar Belakang, Model Pendekatanya, Jurnal Bina Mulia Hukum, Volume 1, Nomor 1, September 2016.

Toto Tohir Suriaatmadja, Rekontruksil Budaya

Hukum Nasional yang Berbasis Nilai-nilai

Budaya Hukum Bangsa Indonesia, Jurnal Hukum, FH.UNISBA. 
Risa Restiyanda, Penyelesaian Sengketa Dagang Internasional Melalui Mediasi Sebagai Alternatif....

VOL. XIII. NO. 1 Maret 2011.

\section{Internet}

Badan Arbitrase Nasional, dalam artikel https://www.baniarbitrati on.org/ina/index.php

Binus, Sumber Hukum Perdagangan Internasional, dalam artiker http://ibm-binus-

5s.blogspot.co.id/2013/04/sumber -hukum-perdaganganinternasional.html.

AndiTonang, Sistem Ekonomi Syariah dalam Perdagangan Internasional https://www.academia.edu/52475 55/Sistem_Ekonomi_Syariah_dal am_Perdagangan_Luar_Negeri. Anditriyawan, Perdaganagan Internasional Dalam Islam, artikel dalam https://anditriyawan85.wordpress. com/2016/10/12/perdaganganinternasional-dalam-pandanganislam/.

HukumOnline,

https://www.hukumonline.com/be

rita/baca/hol20192/sang-juru-

damai-itu-bernama-mediator. http://muazzul.blog.uma.ac.id/wpcontent/uploads/sites/165/2016/12 $\underline{\text { Sejarah-Perkembangan-Mediasi- }}$ di-Indonesia.docx.

Moondoggie, Perdagangan Internasional, dalam artikel https://moondoggiesmusic.com/pe rdagangan-internasional/.

Perkembangan Mediasi di

Indonesia, dalam artikel 